\title{
Life Table Analysis for Evaluating Curative-effect of One-stage Non-submerged Dental Implant in Taiwan
}

\author{
Miin-Jye Wen ${ }^{1}$, Chuen-Chyi Tseng ${ }^{2}$ and Cheng K. Lee ${ }^{3}$ \\ ${ }^{1}$ National Cheng-Kung University, \\ ${ }^{2}$ Chi-Mei Medical Center and ${ }^{3}$ Wachovia Corporate
}

\begin{abstract}
According to the available literature, long-term survival and success rates of one-stage, non-submerged dental implant (A dental implant is not totally buried beneath the gum.) are predictable. However, until now there is no similar study in Taiwan regarding to the efficacy of one-stage, non-submerged dental implant. This prospective study from August 1997 to the end of 2005 includes 316 patients who received the dental implants and prosthesis and were followed up at least 6 months. The total implants are 717. Life table analysis is used to analyze the effectiveness of the onestage, non-submerged dental implant. Our result indicates the survival rate and success rate are $99.58 \%$ and $96.13 \%$, respectively, from this seven-year follow-up study. This study strongly demonstrates that the efficacy of onestage, non-submerged dental implant is also predictable in Taiwan if the patients are under regular follow-up after active treatments.
\end{abstract}

Key words: Cumulative success rate, cumulative survival rate, life table analysis, one-stage non-submerge dental implant.

\section{Introduction}

The application of osseointegrated dental implant on oral rehabilitation has been existing for years. This type of implant has been called "the next best thing to natural teeth". The concept of ossecointegration first described by the research group Brånemark et al. (1969). In the early 1980s Brånemark published his study that showed titanium implants placement through the gum could be integrated into the bone (osseointegrated) if left buried under the gum (submerged) for six months (Adell et al. (1981)). During the 15 years of their retrospective clinical study, the success rates of the maxilla ${ }^{2}$ implants and the mandible ${ }^{3}$ implants were, respectively, $78 \%$ and $86 \%$. However, the technique by Brånemark's team

\footnotetext{
${ }^{2}$ The maxilla is the bone of the upper jaw.

${ }^{3}$ The mandible is the bone of the lower jaw.
} 
required two-stage implants, and, thus, implant patients needed to receive two surgeries before abutment connection causing the inconvenience of both dentists and patients as pointed out by Steenberghe and Naert (1998). Therefore, the simplified one-stage non-submerged ITI implant (International Team for Oral Implantology) was introduced by Schroeder et al. (1993), Wilson (1993) and Buser et al. $(1998,1999)$. The success rate of ITI implant depends on the cooperative work from teams of prosthodontist, periodontist, oral surgeon, and on occasion other dental specialties if needed. The teamwork is also the key to render a high-quality treatment to patients. The features of ITI implant include ossesointegration or so called ankylotic anchorage, usage of the grade IV commercially pure titanium, titanium plasma sprayed (TPS) surface, sandblasted, large-grit and acid-etched (SLA) surface, notably shortening patient's chair time restoration and avoiding the second surgical procedure. In an 8-year prospective clinical study by Buser et al. (1997), the overall success rate of ITI implant was $93 \%$ with $87 \%$ success rate in maxilla implants and $95 \%$ success rate in mandible implants. They have studied that the success rate of ITI implant was very high.

There is no longitudinal study in Taiwan on ITI implant, all the lectures and data can only be found in other countries. Therefore, there is a demand for such a study to be conducted on Taiwanese patients. However, it would presumably increase the success rate in dental implants if any related research has been done in Taiwan (Tseng et al. $(1998,2001,2002,2005)$ ). The applied life table analysis of Cutler and Ederer (1958) is a reliable statistical method to evaluate the longterm prognosis of dental implant (Buser et al. (1997)). In addition, in order to compare with results of Buser et al. (1997), we employ the same life table analysis as the Cutler and Ederer (1958) to calculate survival and success rates, respectively. Hence, this one-stage non-submerged dental implant study is to be evaluated by the life table analysis described by Cutler and Ederer (1958). In a total of 316 patients, 717 implants were consecutively inserted at Chi-Mei Medical Center from August 1997 to end of 2005. Subsequently, all consecutive implants were annually documented up to seven years. This data set belongs to type III censoring in which the subjects (implants, in our study) enter the study in different time periods (see Lee and Wang (2003), pp.2-3). The data set with descriptive statistics are described in Section 2. Methodology applied in analyzing the data is given in Section 3 followed by the results and conclusions in Sections 4 and 5. It can be concluded that one-stage non-submerged ITI implants maintain survival and success rates well above $90 \%$ for observation periods up to 7 years.

\section{Data Description}

The data for this 7-year prospective study encompass patients receiving one- 
stage non-submerged ITI implant since August 1997 received at Chi-Mei Medical Center in Tainan County, Taiwan. Each implant was recorded including surgical part and prosthesis part. The data collection ended in December 2005 with 316 patients receiving the implants. There are two implants was removed within 3 months due to early infection after implant surgery. One implant was removed after 6-month loading (To restore an implant into functional occlusion.). The early implant failure rate is $0.42 \%$. During the follow-up period, 79 implants did not follow the schedule completely and came back for examination sporadically. Among the 316 patients with the average age 43.18, 171 were female $(54.1 \%)$ with the average age 41.17 at the time of the implant while 145 were male (45.9\%) with the average age 45.54 at the time of the implant. Totally, 717 ITI implants with a mean follow-up of 2.99 years received by these patients during the study. It showed that $229(31.9 \%)$ out of the total 717 were implanted in maxilla and the rest of 488 (68.1\%) were in mandible. The majority of the implants was in the rear area where teeth were more likely damaged because they were highly frequently used and were difficult to clean up. The implant positions with respect to the front teeth were divided into maxillary, mandibular, left and right area. Because of the less functionality, wisdom teeth were always extracted without implants when problems occured. The majority had 12-mm implants in length with 261 (36.4\%) implants followed by 249 (34.7\%) 10-mm implants. In general, 10-mm to 12-mm implants were more favorable because of the desirable results. An implant was considered a success, otherwise, a failure if there was no functional signs of pain or discomfort, inflammation or infection during the clinical examination, implant mobility, radiolucency or radiographically detectable bone loss recurrent according to Buser et al. (1997).

\section{Methods}

The life table analysis proposed Cutler and Ederer (1958) was applied to the data. Terms and calculations are defined as follows.

- $t_{i}-i^{\text {th }}$ time interval, $i=1, \ldots, 7$.

The duration of the study is divided into 7 intervals of one year, i.e., $t_{1}=$ $[0-1), t_{2}=[1-2), \cdots$, etc as shown in Table 1 .

- $a_{i}$ - number of implants at the beginning of $t_{i}$

For example, there are 717 implants in $[0-1)$ year in Table 1.

- $b_{i}$ - number of dropouts in $t_{i}$

The individuals left the study and failed to follow up. In Table 1, there were 11 dropouts in $[0-1)$ year time interval. 
- $r_{i}$ - number of implants at risk in $t_{i}$ $r_{i}=a_{i}-b_{i} / 2$, where $b_{i} / 2$ is used as the correction factor for unaccountable dropouts. For example, there were 711.5 implants under risk in $[0-1)$ year in Table 1.

- $S_{i}$ - survival rate in $t_{i}$ $S_{i}=1-n_{i} / r_{i}$ where $n_{i}$ is the number of failures in $t_{i}$. Note that the failures are due to the peri-implant infection. For example, the survival rate in $[0-1)$ year was $99.58 \%$ in Table 1 .

- $C S_{i}$ cumulative survival rate of $t_{i}$ $C S_{i}=S_{1} \times S_{2} \times \cdots \times S_{i}$ the cumulative survival rate of $i^{\text {th }}$ time interval is the product of the survival rate up to time interval $i$.

- $P_{i}$ successful rate in $t_{i}$ $P_{i}=1-m_{i} / r_{i}$ where $m_{i}$ is the number of peri-implant infection in $t_{i}$. For example, the successful rates of $[0-1)$ year and $[1-2)$ year were, respectively, $99.58 \%$ and $98.56 \%$ in Table 2 .

- $C P_{i}$ cumulative successful rate of $t_{i}$ $C P_{i}=P_{1} \times P_{2} \times \cdots \times P_{i}$, the cumulative successful rate of $i^{\text {th }}$ time interval is the product of the successful rate up to time interval $i$. For example, the cumulative successful rates of $[0-1)$ year and $[1-2)$ year were, respectively, $99.58 \%$ and $98.14 \%$ in Table 2.

\section{Results}

There were 2 early failures due to peri-implant infection after surgery and one implant failure in 6-month functioning loading. The early failure rate was $0.42 \%$ lower than the $0.55 \%$ rate reported by Buser et al. (1997). After 6-month functioning loading, 11 implants did not fulfill the predefined criteria of success. There were 79 (11.0\%) implant dropouts, higher than the $5.4 \%$ dropout rate of the seventh year in Buser et al.'s (1997) study. The reasons for our high dropout rate include patients' changing dentists, financial status, and the epidemic of SARS. By the definitions of Section 3, the survival rate and the successful rate of each time interval of the 717 implants are shown in Table 1 and 2 respectively. The cumulative survival rate and the cumulative successful rate were, respectively, $99.58 \%$ and $96.13 \%$. For the results on the implant locations, the cumulative successful rate for the 229 maxillary implants was $94.06 \%$ as shown in Table 3 . The cumulative successful rate for the 488 mandibular implants was $96.83 \%$ as shown in Table 4. Contrary to Buser et al. (1997), our results did not show differences between maxillary and mandibular implants. As to the results on 
different types of implant surface, the cumulative successful rate of the 524 SLA implants was $98.82 \%$ as shown in Table 5. The cumulative successful rate of the 193 TPS implants was $94.42 \%$ as shown in Table 6 .

Table 1: Life table analysis of 717 implants for survival implants

\begin{tabular}{lcccccc}
\hline Interval & $\begin{array}{c}\text { Implants } \\
\text { at start } \\
\text { in interval } \\
\left(a_{i}\right)\end{array}$ & $\begin{array}{c}\text { Failures } \\
\text { during } \\
\text { interval } \\
\left(n_{i}\right)\end{array}$ & $\begin{array}{c}\text { Drop-outs } \\
\text { during } \\
\text { interval } \\
\left(b_{i}\right)\end{array}$ & $\begin{array}{c}\text { Implants } \\
\text { at } \\
\text { risk } \\
t_{i}\end{array}$ & $\begin{array}{c}\text { Survival } \\
\text { rate within } \\
\text { period(\%) } \\
\left(S_{i}\right)\end{array}$ & $\begin{array}{c}\text { Cumulative } \\
\text { survival } \\
\text { rate }(\%) \\
\left(C S_{i}\right)\end{array}$ \\
\hline$[0-1)$ & 717 & 3 & 11 & 711.5 & 99.58 & 99.58 \\
{$[1-2)$} & 492 & 0 & 12 & 486.0 & 100.0 & 99.58 \\
{$[2-3)$} & 302 & 0 & 14 & 295.0 & 100.0 & 99.58 \\
{$[3-4)$} & 210 & 0 & 16 & 202.0 & 100.0 & 99.58 \\
{$[4-5)$} & 140 & 0 & 8 & 136.0 & 100.0 & 99.58 \\
{$[5-6)$} & 84 & 0 & 12 & 78.0 & 100.0 & 99.58 \\
{$[6-7)$} & 54 & 0 & 6 & 51.0 & 100.0 & 99.58 \\
\hline
\end{tabular}

Table 2: Life table analysis of 717 implants for successful implants

\begin{tabular}{lcccccc}
\hline Interval & $\begin{array}{c}\text { Implants } \\
\text { at start } \\
\text { in years interval } \\
\left(a_{i}\right)\end{array}$ & $\begin{array}{c}\text { Failures } \\
\text { during } \\
\text { interval } \\
\left(n_{i}\right)\end{array}$ & $\begin{array}{c}\text { Drop-outs } \\
\text { during } \\
\text { interval } \\
t_{i}\end{array}$ & $\begin{array}{c}\text { Implants } \\
\text { at } \\
\text { risk } \\
\left(r_{i}\right)\end{array}$ & $\begin{array}{c}\text { Success } \\
\text { rate within } \\
\text { period(\%) } \\
\left(P_{i}\right)\end{array}$ & $\begin{array}{c}\text { Cumulative } \\
\text { success } \\
\text { rate }(\%) \\
\left(C P_{i}\right)\end{array}$ \\
\hline$[0-1)$ & 717 & 3 & 11 & 711.5 & 99.58 & 99.58 \\
{$[1-2)$} & 492 & 7 & 12 & 486.0 & 98.56 & 98.14 \\
{$[2-3)$} & 302 & 1 & 14 & 295.0 & 99.66 & 97.81 \\
{$[3-4)$} & 210 & 2 & 16 & 202.0 & 99.01 & 96.84 \\
{$[4-5)$} & 140 & 1 & 8 & 136.0 & 99.27 & 96.13 \\
{$[5-6)$} & 84 & 0 & 12 & 78.0 & 100.0 & 96.13 \\
{$[6-7)$} & 54 & 0 & 6 & 51.0 & 100.0 & 96.13 \\
\hline
\end{tabular}

Table 3: Cumulative success rates of 229 implants in the maxilla

\begin{tabular}{lcccccc}
\hline Interval & $\begin{array}{c}\text { Implants } \\
\text { at start } \\
\text { in interval } \\
\left(a_{i}\right)\end{array}$ & $\begin{array}{c}\text { Failures } \\
\text { during } \\
\text { interval } \\
\left(n_{i}\right)\end{array}$ & $\begin{array}{c}\text { Drop-outs } \\
\text { during } \\
\text { interval } \\
t_{i}\end{array}$ & $\begin{array}{c}\text { Implants } \\
\text { at } \\
\text { risk } \\
\left(r_{i}\right)\end{array}$ & $\begin{array}{c}\text { Success } \\
\text { rate within } \\
\text { period(\%) } \\
\left(P_{i}\right)\end{array}$ & $\begin{array}{c}\text { Cumulative } \\
\text { success } \\
\text { rate }(\%) \\
\left(C P_{i}\right)\end{array}$ \\
\hline$[0-1)$ & 229 & 0 & 2 & 228.0 & 100.0 & 100.0 \\
{$[1-2)$} & 132 & 3 & 6 & 129.0 & 97.67 & 97.67 \\
{$[2-3)$} & 80 & 0 & 5 & 77.5 & 100.0 & 97.67 \\
{$[3-4)$} & 55 & 2 & 2 & 54.0 & 96.30 & 94.06 \\
{$[4-5)$} & 38 & 0 & 3 & 36.5 & 100.0 & 94.06 \\
{$[5-6)$} & 25 & 0 & 5 & 22.5 & 100.0 & 94.06 \\
{$[6-7)$} & 17 & 0 & 2 & 16.0 & 100.0 & 94.06 \\
\hline
\end{tabular}


M-J Wen, C-C. Tseng and C. K. Lee

Table 4: Cumulative success rates of 488 implants in the mandible

\begin{tabular}{lcccccc}
\hline $\begin{array}{l}\text { Interval } \\
\text { in years }\end{array}$ & $\begin{array}{c}\text { Implants } \\
\text { at start } \\
\text { of interval } \\
\left(a_{i}\right)\end{array}$ & $\begin{array}{c}\text { Failures } \\
\text { during } \\
\text { interval } \\
\left(n_{i}\right)\end{array}$ & $\begin{array}{c}\text { Drop-outs } \\
\text { during } \\
\text { interval } \\
\left(b_{i}\right)\end{array}$ & $\begin{array}{c}\text { Implants } \\
\text { at } \\
\text { risk } \\
\left(r_{i}\right)\end{array}$ & $\begin{array}{c}\text { Success } \\
\text { rate within } \\
\text { period(\%) } \\
\left(P_{i}\right)\end{array}$ & $\begin{array}{c}\text { Cumulative } \\
\text { success } \\
\text { rate }(\%) \\
\left(C P_{i}\right)\end{array}$ \\
\hline$[0-1)$ & 488 & 3 & 9 & 483.5 & 99.38 & 99.38 \\
{$[1-2)$} & 360 & 4 & 6 & 357.0 & 98.88 & 98.26 \\
{$[2-3)$} & 222 & 1 & 9 & 217.5 & 99.54 & 97.81 \\
{$[3-4)$} & 155 & 0 & 14 & 148.0 & 100.0 & 97.81 \\
{$[4-5)$} & 102 & 1 & 5 & 99.5 & 99.00 & 96.83 \\
{$[5-6)$} & 59 & 0 & 7 & 55.5 & 100.0 & 96.83 \\
{$[6-7)$} & 37 & 0 & 4 & 35.0 & 100.0 & 96.83 \\
\hline
\end{tabular}

Table 5: Cumulative success rates of 524 implants with SLA surface

\begin{tabular}{lcccccc}
\hline Interval & $\begin{array}{c}\text { Implants } \\
\text { at start } \\
\text { of interval } \\
\text { in years }\end{array}$ & $\begin{array}{c}\text { Failures } \\
\text { during } \\
\text { interval } \\
t_{i}\end{array}$ & $\begin{array}{c}\text { Drop-outs } \\
\text { during } \\
\text { interval } \\
\left(a_{i}\right)\end{array}$ & $\begin{array}{c}\text { Implants } \\
\text { at } \\
\text { risk } \\
\left(r_{i}\right)\end{array}$ & $\begin{array}{c}\text { Success } \\
\text { rate within } \\
\text { period(\%) } \\
\left(P_{i}\right)\end{array}$ & $\begin{array}{c}\text { Cumulative } \\
\text { success } \\
\text { rate }(\%) \\
\left(C P_{i}\right)\end{array}$ \\
\hline$[0-1)$ & 524 & 1 & 3 & 522.5 & 99.81 & 99.81 \\
{$[1-2)$} & 302 & 3 & 1 & 301.5 & 99.01 & 98.82 \\
{$[2-3)$} & 115 & 0 & 3 & 113.5 & 100.0 & 98.82 \\
{$[3-4)$} & 32 & 0 & 1 & 31.5 & 100.0 & 98.82 \\
{$[4-5)$} & 3 & 0 & 0 & 3.0 & 100.0 & 98.82 \\
\hline
\end{tabular}

Table 6: Cumulative success rates of 193 implants with TPS surface

\begin{tabular}{|c|c|c|c|c|c|c|}
\hline $\begin{array}{l}\text { Interval } \\
\text { in years } \\
t_{i}\end{array}$ & $\begin{array}{c}\text { Implants } \\
\text { at start } \\
\text { of interval } \\
\left(a_{i}\right)\end{array}$ & $\begin{array}{c}\text { Failures } \\
\text { during } \\
\text { interval } \\
\left(n_{i}\right) \\
\end{array}$ & $\begin{array}{c}\text { Drop-outs } \\
\text { during } \\
\text { interval } \\
\left(b_{i}\right) \\
\end{array}$ & $\begin{array}{c}\text { Implants } \\
\text { at } \\
\text { risk } \\
\left(r_{i}\right) \\
\end{array}$ & $\begin{array}{l}\text { Success } \\
\text { rate within } \\
\text { period }(\%) \\
\left(P_{i}\right)\end{array}$ & $\begin{array}{c}\text { Cumulative } \\
\text { success } \\
\text { rate }(\%) \\
\left(C P_{i}\right) \\
\end{array}$ \\
\hline$[0-1)$ & 193 & 2 & 8 & 189.0 & 98.94 & 98.94 \\
\hline$[1-2)$ & 190 & 4 & 11 & 184.5 & 97.83 & 96.80 \\
\hline$[2-3)$ & 187 & 1 & 11 & 181.5 & 99.45 & 96.26 \\
\hline$[3-4)$ & 178 & 2 & 15 & 170.5 & 98.83 & 95.13 \\
\hline$[4-5)$ & 137 & 1 & 8 & 133.0 & 99.25 & 94.42 \\
\hline$[5-6)$ & 84 & 0 & 12 & 78.0 & 100.0 & 94.42 \\
\hline$[6-7)$ & 54 & 0 & 6 & 51.0 & 100.0 & 94.42 \\
\hline
\end{tabular}

\section{Conclusions}

The survival rate and the successful rate of the 717 implants were both greater than 96\% (Table 1 and 2). Comparing to the results of Buser et al. (1997) in 
which the 7-year cumulative survival rate and the cumulative successful rate were, $96.7 \%$ and $94.3 \%$, respectively, the cumulative successful rate in this study was higher and the cumulative survival rate was even better. The reasons may be, first, the data of Buser et al. (1997) was from 3 universities and 2 countries (so called multi-center) and the time frames of the 3 data sets were different. The results of this study should be highly reliable for one-stage non-submerged implant. Moreover, because of the advanced surgical procedures in recent years, the successful rate was presumably better. Secondly, the successful rates of maxillary and mandibular implants were both greater than 94\% (Table 3 and 4), a little different in the two locations. In comparison with the cumulative successful rates of maxillary and mandibular implants in Buser et al.'s (1997), respectively, 87.2\% and $95.6 \%$, the cumulative successful rate of maxillary implants in this study was better while the cumulative successful rate of mandibular implants was not much different. Thirdly, the successful rate of SLA which was adopted in our practice was higher than of TPS (Table 5 and 6 ). Based on our findings, the one-stage non-submerged implant of the ITI should be widely adopted in Taiwan. Therefore, this team-work approach of implant treatment is highly reliable. And, for the quality of ITI implant, we should also continuously update, follow-up and analyze the data.

\section{Acknowledgement}

The study was supported by grant CMFHR9255 from Chi-Mei Medical Center.

\section{References}

Adell, R., Lekholm, U., Rockler, B. and Brånemark, P. I. (1981). A 15-year study of osseointegrated implants in the treatment of edentulous jaw. International Journal of Oral Surgery 10, 387-416.

American Academy of Implant Dentistry (2007). Oral Implantology, glossary of implant terms. Journal of Oral Implantology, Supplement 1, 2-14.

Brånemark, P. I., Breine, U., Adell, R., Hansson, B. O., Lindstrom, J. and Olsson, A. (1969). Intra-osseous anchorage of dental prostheses. I. Experimental studies. Scandinavian Journal of plastic and Reconstructive Surgery 3, 81-100.

Buser, D., Belser, U. C. and Lang, N. P. (1998). The original one-stage dental implant system and its clinical application. Periodontology 2000 17, 106-118.

Buser, D., Mericske-Stern R., Bernard, J. P., Behneke, A., Behneke, N., Hirt, H. P., Belser, U. C. and Lang, N. P. (1997). Long-term evaluation of non-submerged ITI implants. Part1:8-year life table analysis of a prospective multi-center study with 2359 implants. Clinical Oral Implants Research 8, 161-172. 
Buser, D., Mericske-Stern R., Dula, K. and Lang, N. P. (1999). Clinical experience with one-stage non-submerged dental implants. Advanced Dental Research 13, 153-161.

Buser, D., Weber, H. P. and Lang, N. P. (1990). Tissue integration of non-submerged implants. 1-year result of prospective study with 100 ITI hollow-cylinder and hollow-screw implants. Clinical Oral Implants Research 11, 33-40.

Cutler, S. J. and Ederer, F. (1958). Maximum utilization of the life table method in analyzing survival. Journal of Chronic Disease 8, 699-712.

Lee, E. T. and Wang, J. W. (2003). Statistical Methods for Survival Data Analysis, 3rd Edition. John Wiley and Sons.

Schroeder, A., Sutter, F., Buser, D. and Krekeler, G. (1993). Oral implantology: basics, ITI hollow cylinder system, $2^{\text {nd }}$ edition. New York Thieme Medical Publishers, Inc..

Steenberghe, D. V. and Naert, I. (1998). The first two-stage dental implant system and its clinical application. Periodontology 2000 17, 89-95.

Tseng, C. C., Chen, Y. H. M., Pang, I. C. and Weber, H. P. (2005). Peri-implant pathology caused by periapical lesion of an adjacent natural tooth: a case report. International Journal of Oral \&3 Maxillofacial Implants 203, 632-635.

Tseng, C. C., Huang, K. C., Pang, I. C. and Lee, C. H. (2001). The Soft Tissue Management in the Implantation of ITI One-stage Dental Implant. Chinese Journal Periodontology 6, 21-27.

Tseng, C. C., Pang, I. C., Huang, K. C., Lee, C. H., Liu, S. Y. and Wen, M. J. (2002). Clinical experience of team approach on one-stage nonsubmerged implant treatment: A up to four years follow-up. Chinese Journal Periodontology 7, 59-65. (in Chinese).

Tseng, C. C., Tsai, G. C. and Lee, C. H. (1998). Insertion of ITI dental implants for maxillary posterior region using osteotomies: technique and case reports. Chinese Journal Periodontology 3, 77-83. (in Chinese)

Wilson, T. G. (1993). ITI Dental Implants: Planning, Placement, Restoration, and Maintenance. Quintessence Pub.

Received March 4, 2007; accepted May 21, 2007. 
Miin-Jye Wen

Department of Statistics

National Cheng-Kung University

Tainan city, Taiwan 70101

mjwen@stat.ncku.edu.tw

Chuen-Chyi Tseng

Dental Department

Chi-Mei Medical Center

Tainan county, Taiwan 710

jimtseng@ms15.jinet.net

Cheng K. Lee

Targeting Modeling Team

Insight \& Innivation Market Division

Wachovia Corprate

201 S. College Street

Chaolotte, NC 28244, USA

cheng.lee@wachovia.com 